IRA-International Journal of Education \& Multidisciplinary Studies

ISSN 2455-2526; Vol.14, Issue o2 (February, 2019)

Pg. no. 26-36.

Institute of Research Advances

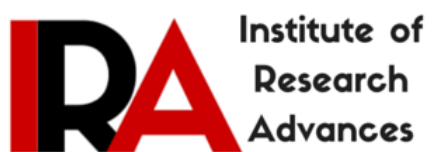

http://research-advances.org/index.php/IJEMS

\title{
Design and Implementation of Thematic Assignment in Integrating the Local Context - Concepts - Global Context
}

\author{
Theresje Mandang ${ }^{1}$ \& Christophil S. Medellu ${ }^{2 \#}$ \\ ${ }_{1,2}$ Department of Physics Education, Faculty of Science and Mathematics, University of Manado, \\ Indonesia.
}

\# corresponding author.

Type of Work: Peer Reviewed

DOl: http://dx.doi.org/10.21013/jems.v14.n2.p2

\section{How to cite this paper:}

Mandang, T., Medellu, C.S. (2019). Design and Implementation of Thematic Assignment in Integrating the Local Context - Concepts - Global Context. IRA International Journal of Education and Multidisciplinary Studies (ISSN 2455-2526), 14(2), 26-36.doi: http://dx.doi.org/10.21013/jems.v14.n2.p2

(C) Institute of Research Advances.

This work is licensed under a Creative Commons Attribution-Non Commercial 4.0 International License subject to a proper citation to the publication source of the work.

Disclaimer: The scholarly papers as reviewed and published by the Institute of Research Advances (IRA) are the views and opinions of their respective authors and are not the views or opinions of the IRA. The IRA disclaims of any harm or loss caused due to the published content to any party.

Institute of Research Advances is an institutional publisher member of Publishers International Linking Association Inc. (PILA-CrossRef), USA. The institute is an institutional signatory to the Budapest Open Access Initiative. Hungary advocating the open access of scientific and scholarly knowledge. The Institute is a registered content provider under Open Access Initiative Protocol for Metadata Harvesting (OAI-PMH).

The journal is indexed \& included in WorldCat Discovery Service (USA), CrossRef Metadata Search (USA), WorldCat (USA), OCLC (USA), Open J-Gate (India), EZB (Germany) Scilit (Switzerland), Airiti (China), Bielefeld Academic Search Engine (BASE) of Bielefeld University, Germany, PKP Index of Simon Fraser University, Canada. 


\begin{abstract}
Utilization of the surrounding environment as a learning resource is considered superior in improving comprehensively the knowledge, psychomotor and student affection. Learning about the environment (nature, socio-culture) allows new information to enrich the experience gained by students from outside the classroom. The surrounding environment-based learning should be enriched with information from relevant external sources, among others through mass media or reference/learning resources. Learning comes from the surrounding environment is very relevant and useful for schools (junior and senior high school) in the small island that experienced problems of lack of teaching materials, and the limitations of teachers. An interesting learning strategy in the development of learning comes from the surrounding environment is to compile and associate facts and phenomena (nature and social culture) that is around with external information that is passed through mass media or printed sources, photographs etc. This article discusses the design and experimental design of teaching in the form of thematic tasks that emphasize the learning process through comparison activities and local context associations with global context based on the concept of science and mathematics. The results of the experiments show that the group of students have the motivation and active activities of comparison and association of local context with global, although the mastery of science and mathematics concepts are not so good. Students generally perceive good and excellent design and testing of learning activities.
\end{abstract}

Keywords: local context, global context, integration, comparison, association

\title{
Introduction
}

The principle of constructivism emphasizes that human beings build their knowledge from what it faces in an integrated way (Unal and Akpinar, 2006). The integration of concepts with facts, phenomena, issues in the environment is important to be developed as a unity of learning materials. Berlin and White (1995) in Stohlmann (2012) recommend approaches that need to be done in building children's knowledge, among others: (1) building knowledge based on previous students' knowledge, (2) organizing knowledge in the frame of idea or concept or theme, 3) developing students' knowledge to include conceptual relationships with processes, (4) understanding that knowledge is situational or is a specific context. This approach indicates two important principles: new knowledge or information must be relevant to previous student experiences and lessons that utilize multiple learning resources. Lattuca et al. (2004) suggests that learning that utilizes multiple sources of information builds students' ability to organize and connect new information, construct a deeper knowledge scheme Relevant expansion of conceptcontext relationships (natural phenomena, socio-cultural issues) will increase interest, retention as students obtain information from multiple sources (Khodar et al., 2004; Chamany et al., 2008). The surrounding environment context also allows students to perform activities such as observation, experimentation or research steps and reflect the values of science, social-culture in society on what it observes. Connected learning is defined as learning that utilizes information technology to acquire Stohlmann et al (2012) resources or learning materials, enabling teachers to develop a learning focus on the big ideas connected between subjects (Stohlmann et al, 2011). Using a network system students understand the relationship of facts, phenomena, issues that exist in the environment around with what happens globally. According to Morrison (2006) in Stohlmann et al. (2012), benefits of information technology use include: students become more capable solve problems, innovate, find, think critically, be more confident, and become technology literate.

Small islands have special characteristics and have shaped the knowledge, skills, attitudes and behaviour of society, as one unity of the learning context. The context of learning, based on the characteristics of small island ecosystems, includes biophysical, socio-cultural and economic components (Mercer et al., 2007) as a whole. The integration of local knowledge with the global / external to communities on small islands is an essential part of developing Ecosystem-based Adaptation (EbA) (Merce et al, 2007), to produce context-relevant problem solving methods (Moler et al, 2004) building knowledge and awareness towards the use of resources and environmental conservation (Kellerts et al., 2000). Conditions on small islands where there is no internet access can be pursued by preparing videos, photos, data or external information relevant to local conditions as a focus of science-based learning activities. This strategy allows students to understand events or phenomena that occur elsewhere and their relationships (comparisons, associations, differentiation) with local facts/phenomena experienced directly. Packaging of learning materials utilizing technology (eg video utilization) can encourage students to be more passionate and gain more information and can remember more ideas (Chen, 2012). The most important thing in the development of such thematic learning is the design and availability of materials for students to carry out thematic 
instructions or conduct their own initiative. This research describes the mechanism of designing and piloting the implementation of coastal abration tematic designs with the approach of compiling and associating local context global context - concepts.

\section{Method}

The research method of developing this thematic design discusses the design method and the result of the design try-out which becomes the feedback for the improvement of teacher role, design and scenario parent/community in a student learning activity.

1. Design of instructional material

a. Define the theme and scope of the thematic assignment

The theme of the task is determined based on facts or phenomena or issues that occur/experienced by people in small islands. This is a requirement for local context setting. The determination of this issue ensures: (1) the relevance of learning materials (concepts and contexts) to the experiences, needs and issues of student questions, (2) enables parent and community participation due to the experience and need to learn more about the substance of learning, socio-cultural values, local wisdom etc to the young generation.

b. Identification of small island ecosystems and ecosystem components

Small island. spatially reachable (visual) so as to allow for observation or field measurement. The people of the small island are relatively homogeneous, making it easier to identify and formulate the socio-cultural aspects associated with facts and phenomena occurring in the environment, as part of the local context.

c. The formulation of the thematic assignment items with the scenario as presented in Figure-1.

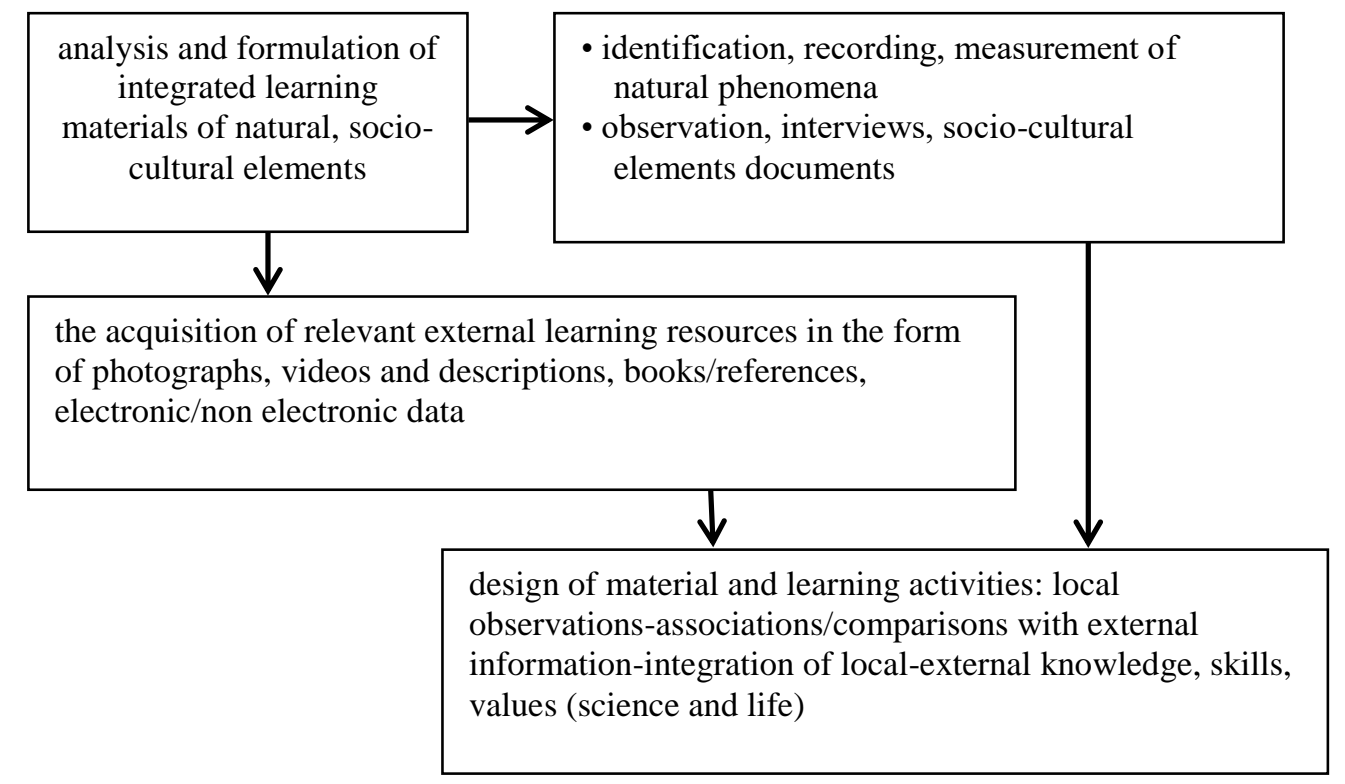

Figure 1. Thematic design mechanism: local-global context integration

2. Identification of local components (fact/phenomenon of nature and social culture)

Identification of local components and matches with external or global elements using the following forms:

Table-1. A form of object identification - a natural phenomenon

\begin{tabular}{|l|l|l|l|l|}
\hline no & Object category & location & Description of facts/phenomena/ characteristics of the object & Object code \\
\hline & & & & \\
\hline & & & & \\
\hline
\end{tabular}


Table-2. A form of identification of socio-cultural elements related to natural objects

\begin{tabular}{|l|l|l|l|l|}
\hline no & $\begin{array}{l}\text { Object } \\
\text { code }\end{array}$ & $\begin{array}{l}\text { Description of community } \\
\text { attitudes }\end{array}$ & $\begin{array}{l}\text { Description of community } \\
\text { behaviour }\end{array}$ & $\begin{array}{l}\text { Related } \\
\text { wisdom }\end{array}$ \\
\hline & & & & \\
\hline & & & & local \\
\hline
\end{tabular}

Table-3. Form analysis of natural components - social culture

\begin{tabular}{|c|c|c|c|c|}
\hline no & $\begin{array}{l}\text { Object } \\
\text { code }\end{array}$ & $\begin{array}{l}\text { Components of natural science learning } \\
\text { (conceptual and procedural components) }\end{array}$ & $\begin{array}{l}\text { Description } \\
\text { community } \\
\text { intervention }\end{array}$ & $\begin{array}{lr}\text { Category } & \text { of } \\
\text { intervention } & \text { and } \\
\text { explanation } & \end{array}$ \\
\hline & & & & \\
\hline & & & & \\
\hline
\end{tabular}

Table-4. A form of acquiring external learning materials

\begin{tabular}{|l|l|l|l|l|l|}
\hline no & $\begin{array}{l}\text { Local object } \\
\text { code }\end{array}$ & $\begin{array}{l}\text { Description of local } \\
\text { components }\end{array}$ & $\begin{array}{l}\text { Description of the relevance of external/global } \\
\text { components }\end{array}$ \\
\cline { 3 - 6 } & & Natural & Socio-cultural & natural & Socio-cultural \\
\hline & & & & & \\
\hline & & & & & \\
\hline
\end{tabular}

Table-5 Form analysis of the conceptual linkage between natural component (or socio-cultural) localexternal

\begin{tabular}{|l|l|l|l|l|l|}
\hline no & $\begin{array}{l}\text { Object } \\
\text { code }\end{array}$ & $\begin{array}{l}\text { Local components } \\
\text { (nature) }\end{array}$ & $\begin{array}{l}\text { External } \\
\text { component }\end{array}$ & $\begin{array}{l}\text { The concept } \\
\text { applies/connects }\end{array}$ & $\begin{array}{l}\text { The concept } \\
\text { network }\end{array}$ \\
\hline & & & & & \\
\hline & & & & & \\
\hline
\end{tabular}

Table-6. Form for analysis the procedural linkages of natural component (or socio-cultural)

\begin{tabular}{|l|l|l|l|l|l|}
\hline no & $\begin{array}{l}\text { Object } \\
\text { code }\end{array}$ & $\begin{array}{l}\text { Procedural local } \\
\text { comp }\end{array}$ & $\begin{array}{l}\text { Procedural: } \\
\text { external comp }\end{array}$ & $\begin{array}{l}\text { Code of procedural } \\
\text { conformity }\end{array}$ & $\begin{array}{l}\text { Description of fusion } \\
\text { (integration procedure) }\end{array}$ \\
\hline & & & & \\
\hline & & & & & \\
\hline
\end{tabular}

Table-7. Form for analysis the natural component values (or socio-cultural) local-external

\begin{tabular}{|l|l|l|l|l|l|l|}
\hline no & $\begin{array}{l}\text { Object } \\
\text { code }\end{array}$ & $\begin{array}{l}\text { Form of } \\
\text { intervention } \\
\text { (local) }\end{array}$ & $\begin{array}{l}\text { Perception of } \\
\text { values (local) }\end{array}$ & $\begin{array}{l}\text { Local } \\
\text { wisdom }\end{array}$ & $\begin{array}{l}\text { Form } \\
\text { intervention } \\
\text { (external) }\end{array}$ & $\begin{array}{l}\text { Association and adoption } \\
\text { of values and forms of } \\
\text { intervention }\end{array}$ \\
\hline & & & & & \\
\hline
\end{tabular}

3. Analysis methods for design of assignment material in integrating local context - concepts global / external; context 
Figure-2. presents an analytical flow chart for designing thematic task materials that integrate Local Context (KL) - Concepts (Ks) - Global Context (KG)

The elements of the material analyzed are

KL-1: local issues (observable or not observable)

KL-2: observable phenomenon of KL-1 (one KL-1 can include several KL-2)

KL-3: a factor affecting KL-2 (for each KL-2 can include more than one KL-3)

KL-4: variables of KL-2

KL-5: variables of KL-3

Ks-1: physical/science relationships, mathematics between variables KL-4 and KL-5, and between the variable of KL-4 with KL-5

Ks-2: conceptual formulation of physics/sains, mathematics of Ks-1

Ks-3: general nature / generalization of Ks-2

Ks-4: specific variation of Ks-2 with the conditioning (related to local and global condition)

KG-1: global issues (observable or not observable)

KG-2: observable phenomenon pf KG-1 (one KG-1 can include several KK-2)

KG-3: a factor affecting KG-2

KG-4: variables of KG-2

KG-5: variables of KG-3

Flowchart of material analysis for the design of thematic assignment to integrating local context - global context - concept presented in Figure 2

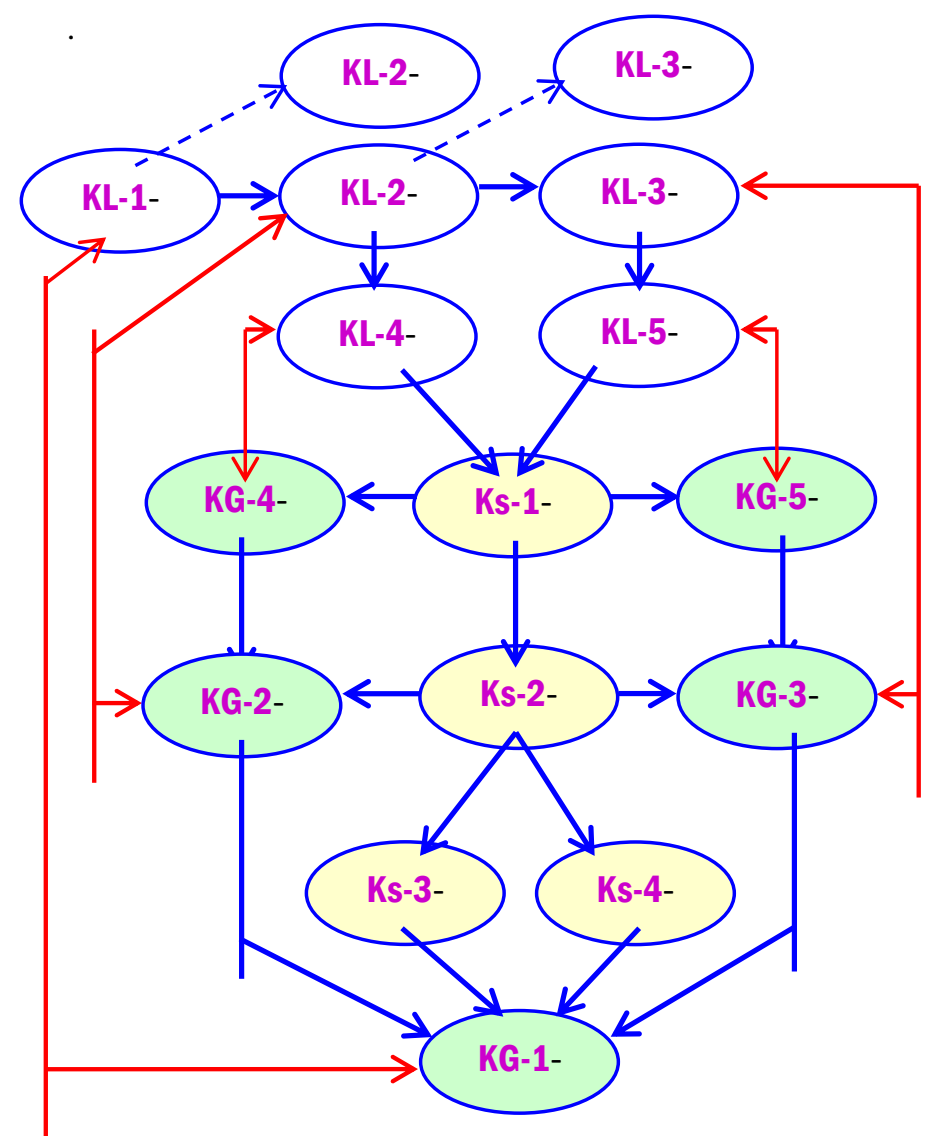

Figure-2. Flowchart analysis of thematic assignment design material using the KL - Ks - KG approach 
4. The design of learning scenarios

Learning scenarios can be designed to vary, but basically, are based on observations of natural and socio-cultural phenomena. The learning of natural and socio-cultural can be done by variation: (1) natural facts/phenomena followed by discussion of socio-cultural components, or (2) discussion of issues or sociocultural issues followed by discussion of facts / natural phenomena (resource and environmental conditions) 3) discussion of simultaneous facts or natural phenomena with related socio-cultural elements. The 3rd approach is known as socioscientific approach. The design of activities developed in this study is using the design (2) and (3). The design of materials and activities of thematic assignment using the participatory approaches of students, parents, and community. The form for the design of learning activity (thematic assignment) in integrating the local context-concept-global context was presented in Table-8 (referring to flow chart-Figure-2)

Table-8. Design form for learning activities based on material analysis with KL-Ks-KG approach

\begin{tabular}{|c|c|c|c|c|c|c|c|c|c|c|c|c|c|}
\hline \multicolumn{5}{|c|}{ Kicak context } & \multicolumn{5}{c|}{ Concept } & \multicolumn{5}{c|}{ Global/external context } \\
\hline KL-1 & KL-2 & KL-3 & KL-4 & KL5 & Ks-1 & Ks-2 & Ks-3 & Ks-4 & KG-1 & KG-2 & KG-3 & KG-4 & KG-5 \\
\hline a & c & d & g,h,j & g,h,j & j & d,e,f,i & e,f & e,f & b & 1 & 1 & k & k \\
\hline & & & & & & & & & & & & & \\
\hline & & & & & & & & & & & & & \\
\hline
\end{tabular}

The choice of analytical activities in integrating the local context - the concept - the global context

a. discussion of issues (local context or global context)

b. discussion of issues and discussion of references to comparisons the local problems with global or external issues

c. discussions of identification and formulation of phenomena (local and global) that can be observed and which can not be observed

d. discussion for formulation the scope, the sequence of phenomena, and the factors that influence

e. identification and formulation of concept that relevant to issues

f. validation of identified concepts by expert or facilitator or resource person

g. identification of variables through observation and using references

h. validation of identified variables by expert or facilitator or resource person

i. the formulation of concept networks describing phenomena and factors affecting phenomena

j. determining which variables can be observed or measured, and variables that can be calculated or determined from the data of measurable variable.

k. association/comparison/ differentiation between variables of local phenomena with global

1. association/comparison/ differentiation between concepts of local and global phenomena

$\mathrm{m}$. association/comparison/ differentiation of affecting factors and its similarities/differences in local phenomena with global

\section{Research Results}

1. Parents participation in developing design

The thematic assignment which designed, developed and researched here was the coastal abrasion. This theme was the significant issues or problem for the small island community. The basic design covers nine subjects:
a. Understanding coastal ecosystems
b. Studying the function of ecosystem components reduces coastal abrasion
c. Learn the external factors (environment) that affect coastal ecosystems and coastal abrasion
d. Energy changes in coastal ecosystems and the impact on the environment
e. Analyze the impact of garbage accumulation and the flow of liquid waste into coastal ecosystems
f. the utilization of coastal resources and their impacts
g. Identification and description of ecosystem conditions, coastal abrasion in the village and surrounding areas
h. Identification, analysis and description of the influence of human activities on coastal ecosystems 
i. Identification, analysis and description of government programs, local wisdom in the preservation of coastal ecosystems

j. Strengthening programs/activities through technical adaptation and adoption of coastal ecosystem management activities elsewhere as well as personal commitments

In the design development activities (according to local conditions), students provide relevant ideas that to be included in the instructional material and developed in the implementation of design undertaken by the students. Instructional materials that serve as guides for research are distributed to students before they start to work. Then students are given direction to provide relevant ideas to be incorporated into instructional materials as material for developing thematic tasks. However, in the event, there are no ideas given by students as a material development to researchers.

2. The results of the design tryout

The result of group tryout in integrating local context-concept-global context, are presented in Table-9. Table-9. shows in detail the ability of the group to undertake a coastal abrasion thematic task instruction by integrating local context, concept and global/external context. Activity work begins with a discussion of problems, observation/measurement, analysis and discussion of local context followed by analysis and discussion of concept and process of association / comparison with a global context.

The results of the assessment on group achievement (process and the results performs the thematic assignment instruction) presented in Table-10. Scores of each group (a, b, c, and d) for each material/activity characteristic are the average of group scores which obtained by integrating (comparing, associating, combining/linking, equipping) each characteristic with eight other characteristics. Table-10 shows the highest scores in integrating local context-concept-global/external context was through field observation activities directed by teachers and researchers. The result of the observation on the learning process showed that the student group discussed more intensively in the observation activities directed by the teacher and the researcher. The group of students also actively ask teachers and researchers during the implementation of field activities. Student groups also actively obtain information sources related to field activities, either through discussed references that have been provided, using the internet as directed by teachers and researchers and even initiating (developing) learning activities such as using the internet, making additional observations. 


\section{Table-9. Group performance (achievement test) integrates local context - global context-concept}

Theme: coastal abrasion






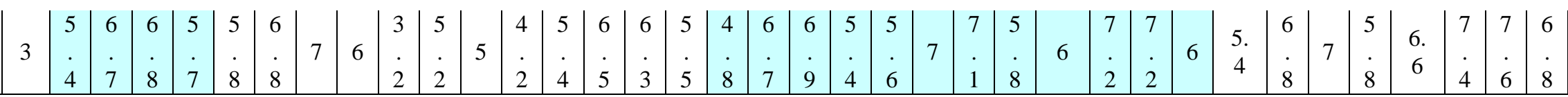

Notes: description of learning material components:

- konteks: (1) description of phenomena and physics law, (2) formulation and mathematical description (3) procedural approach and explanation

- konteks lokal: (1) review of experience, (2) observation (directed), (3) observation (group initiative)

- konteks global: (1)discussion of reference (prepared), (2) internet - directed. (3) internet - group initiative 
Table-10. Results of student achievement learning assessment in integrating the local context -concept global context, according to the material/activity characteristics

\begin{tabular}{|c|c|c|c|c|c|c|}
\hline \multirow[t]{2}{*}{$\begin{array}{l}\text { Comp of teaching } \\
\text { material }\end{array}$} & \multirow[t]{2}{*}{$\begin{array}{l}\text { Characteristic of teaching material (thematic assignment) } \\
\text { component }\end{array}$} & \multicolumn{4}{|c|}{ Group score } & \multirow{2}{*}{ mean } \\
\hline & & a & $\mathrm{b}$ & $\mathrm{c}$ & $\mathrm{d}$ & \\
\hline (1) & (2) & (3) & (4) & (5) & (6) & (7) \\
\hline \multirow[t]{3}{*}{ Concept/ physics law } & Description of physics law \& phenomena & 6.2 & 6.9 & 6.7 & 6.2 & 6.50 \\
\hline & Mathematical formulation and description & 4.5 & 5.1 & 5 & 4.6 & 4.80 \\
\hline & procedural approach and explanation & 6.2 & 7 & 6.9 & 6.2 & 6.58 \\
\hline \multirow[t]{3}{*}{ Local context } & Exploration of experiences & 5.9 & 7 & 6.8 & 6.1 & 6.45 \\
\hline & Observation (directed), & 6.7 & 7.5 & 7.6 & 6.7 & 7.13 \\
\hline & Observation (group initiatives) & 6.6 & 7.5 & 7.5 & 6.6 & 7.05 \\
\hline \multirow[t]{3}{*}{ Global context } & References (prepared & 6 & 7.1 & 7 & 6.2 & 6.58 \\
\hline & Internet - directed & 6 & 7.1 & 7 & 6 & 6.53 \\
\hline & Internet - group initiatives & 5.4 & 6.7 & 6.8 & 5.7 & 6.15 \\
\hline
\end{tabular}

The initiative of observation as an independent development activity by the group is also quite high and this is contributed by development activities directed by teachers and researchers. The lowest average score is on material/activity related to formulation and mathematical description. The weakness of mathematical mastery becomes an obstacle in the process of integrating the local context - concept - global/external context. Concerning the concept component, students have difficulty understanding physical phenomena based on formulations and mathematical approaches. Similarly, in analyzing the data, presenting and interpreting data related to observation activities both directed and become student group initiatives. Mathematical sections such as functions and graphs are usually not analyzed and discussed completely. The mastery of approach and procedural explanation is also lacking. If the mastery of procedural approaches can be improved, this will ensure improved outcomes in conducting field observation activities both directed by teachers and researchers, as well as student group initiatives. Exploration of the student experience is also not maximal, mainly because students are not accustomed to expressing experience in learning activities. Groups of students have difficulty in recognizing the relationship of experience gained in daily life with the concepts of science. The student group shows progress during the process of performing thematic tasks related to the activities of linking and comparing experiences in the surrounding environment with the global information available in the reference. The ability of students to utilize the internet to obtain material is also still a constraint in the process of integrating the local context - concept - the global context.

\section{Conclusion}

Based on the evaluation results of the design process and tryout, the research conclusions are as follows:

1. The form of integrating the local context - concept - global can enrich learning materials and activities (doing thematic assignment)

2. The form of integrating the local context - concept - the global can be widely developed for connecting the physical and socio-cultural phenomena as implications of science learning

3. Learning activities on local phenomena associated with concepts can strengthen the mastery of the relationship between concepts and the context

4. The activity of associating or comparing the local context with the global provides a more comprehensive understanding of natural phenomena as well as its social implications

5. Learning materials and activities about a thematic assignment which enriched by the integration of local contexts - concept - global context can motivate students to undertake the process of science, conduct book reviews and obtain a broad source of learning information. 


\section{References}

[1]. Chen Y. T. 2012. The effect of thematic video-based instruction on learning and motivation in e-learning. International Journal of the Physical Sciences, 7(6): 957 - 965,

[2]. Chamany K.,Allen D., and Tanner K. 2008. Infusing social context in biology teaching. CBE Life Social Education; 7(3): 267-278.

[3]. Kellerts S.R., Mehta J.J,, Ebbin S.A., and Lichtenfeld L.L.2000. Community Natural Resource Management: Promise, Rhetoric, and Reality. Society and Natural Resources, 13:705-715

[4]. Khodar J., Halme D. G., Walker G. C. 2004. A hierarchical biology concept framework. Cell Biol. Educ. 3:111-121.

[5]. Lattuca L., Voigt L., Fath Q. 2004. Does interdisciplinarity promote learning? Theoretical support and researchable questions. Rev. Higher Educ., 28:23-48.

[6]. Mandang T., dan Runtu P.V., 2015. Integrasi konsep dengan konteks local dan global dalam pembelajaran sainsmatematika di Kabupaten Sangihe. Laporan penelitian hibah bersaing. Lemlit Unima.

[7]. Mercer J., Dominey-Howes D., Kelman I., and Lloyd K. 2007. The potential for combining indigenous and western knowledge in reducing vulnerability to environmental hazards in small island developing states. Environmental Hazards. 7: 245-256

[8]. Moller, H., O’Blyver P., Bragg C., Newman J., Clucas R., Fletcher D., Kitson J., McKechnie., Scott,, and Titi R. 2009. Guidelines for cross-cultural participatory action partnerships: a case study of customary seabird harvest in New Zealand. New Zealand Journal of Zoology 36:211-241

[9]. Stohlmann M., Moore T., Roehrig G. and McClelland J. 2011. Year-long impressions of a middle school STEM integration program. Middle School Journal, 43(1): 32-40.

[10]. Stohlmann M., Moore T. J., and G.H. Roehrig. 2012, "Considerations for Teaching Integrated STEM Education. Journal of Pre-College Engineering Education Research (J-PEER): Vol. 2: Iss. 1, Article 4. http://dx.doi.org/10.5703/1288284314653

[11]. Unal G., and Akpinar E. 2006. To what extent science teachers area constructivist in their classrooms?. Journal of Baltic Science Education, 2(10): 40-50

\section{THANK YOU NOTE}

This research was conducted with funding support from DRPM Dikti, so the research team expresses gratitude for this support. The research team also expresses gratitude to Rector Unima, Chairman of Unima Research and Community Service Institute, and colleagues of lecturers who are gathered in the group of natural resources and environmental management expertise and learning. The research team also expresses gratitude to the students of physics education, mathematics education and biology education programs involved in collaborative research. 